\title{
Glacier changes and climate trends derived from multiple sources in the data scarce Cordillera Vilcanota region, southern Peruvian Andes
}

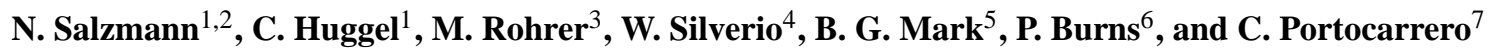 \\ ${ }^{1}$ Department of Geography, University of Zurich, Zurich, Switzerland \\ ${ }^{2}$ Department of Geosciences, University of Fribourg, Fribourg, Switzerland \\ ${ }^{3}$ Meteodat GmbH, Technoparkstrasse 1, Zurich, Switzerland \\ ${ }^{4}$ Institute for Environmental Science, Climate Ch ange and Climate Impact Group, University of Geneva, \\ Geneva, Switzerland \\ ${ }^{5}$ Department of Geography, Ohio State University, Columbus OH, USA \\ ${ }^{6}$ College of Earth, Ocean and Atmospheric Sciences, Oregon State University, Corvallis, OR, USA \\ ${ }^{7}$ Independent Consultant, Huaraz, Peru, formerly at Unidad de Glaciología y Recursos Hídricos, \\ Autoridad Nacional de Agua, Huaraz, Peru
}

Correspondence to: N. Salzmann (nadine.salzmann@geo.uzh.ch)

Received: 15 November 2011 - Published in The Cryosphere Discuss.: 30 January 2012

Revised: 10 October 2012 - Accepted: 15 December 2012 - Published: 23 January 2013

\begin{abstract}
The role of glaciers as temporal water reservoirs is particularly pronounced in the (outer) tropics because of the very distinct wet/dry seasons. Rapid glacier retreat caused by climatic changes is thus a major concern, and decision makers demand urgently for regional/local glacier evolution trends, ice mass estimates and runoff assessments. However, in remote mountain areas, spatial and temporal data coverage is typically very scarce and this is further complicated by a high spatial and temporal variability in regions with complex topography. Here, we present an approach on how to deal with these constraints. For the Cordillera Vilcanota (southern Peruvian Andes), which is the second largest glacierized cordillera in Peru (after the Cordillera Blanca) and also comprises the Quelccaya Ice Cap, we assimilate a comprehensive multi-decadal collection of available glacier and climate data from multiple sources (satellite images, meteorological station data and climate reanalysis), and analyze them for respective changes in glacier area and volume and related trends in air temperature, precipitation and in a more general manner for specific humidity. While we found only marginal glacier changes between 1962 and 1985, there has been a massive ice loss since 1985 (about $30 \%$ of area and about $45 \%$ of volume). These high numbers corroborate studies
\end{abstract}

from other glacierized cordilleras in Peru. The climate data show overall a moderate increase in air temperature, mostly weak and not significant trends for precipitation sums and probably cannot in full explain the observed substantial ice loss. Therefore, the likely increase of specific humidity in the upper troposphere, where the glaciers are located, is further discussed and we conclude that it played a major role in the observed massive ice loss of the Cordillera Vilcanota over the past decades.

\section{Introduction}

Mountain glaciers are a major fresh water resource for people living in, nearby or in the adjacent lowlands of mountain ranges (Barnett et al., 2005). Observed worldwide glacier retreat is thus an important concern for the availability of fresh water in these areas. In the tropics, late 20th century glacier retreat has been observed to be particularly pronounced (IPCC, 2007; Rabatel et al., 2012). Moreover, because of the distinctive outer tropical hydrological seasonality, which is characterized by one dry and one wet season (Kaser, 2001), glacier meltwater often provides a critical 
Table 1. Results of glacier mapping and ice volume estimates. For the 2006 volume estimates, a range is presented, based on a $10 \%$ and $20 \%$ thickness reduction $\left(2006_{10 / 20 \%}\right)$ between 1962 and 2006, and basal shear stress values of 1.0 and 1.2 bar. Note that the numbers for 1962 are based on aerial photographs (inventory), all other numbers on satellite images (see Sect. 3.1).

\begin{tabular}{lrrrr}
\hline Year & $\begin{array}{r}\text { Glacier } \\
\text { area } \\
\left(\mathrm{km}^{2}\right)\end{array}$ & $\begin{array}{r}\text { Percent of } \\
\text { initial area } \\
(\%)\end{array}$ & $\begin{array}{r}\text { Total glacier } \\
\text { volume }\left(\mathrm{km}^{3},\right.\end{array}$ & $\begin{array}{r}\text { Total glacier } \\
\text { volume }\left(\mathrm{km}^{3},\right.\end{array}$ \\
& 440 & 100 & 17.0 & 20.4 \\
1962 & 444 & 101 & & \\
1985 & 344 & 78 & & \\
1996 & 297 & 68 & 10.3 & 12.4 \\
$2006_{10 \%}$ & 297 & 68 & 9.2 & 11.0 \\
$2006_{20 \%}$ & $297)$ \\
\hline
\end{tabular}

source of fresh water in these regions during the dry season (Chevallier et al., 2011; Bradley et al., 2006, 2009).

While the observed global mean trend for glacier retreat is clear, the significance varies between regions and locations (WGMS, 2009). An adequate spatial and temporal coverage of measurements is required to derive trends for a specific region or single glaciers. However, most mountain regions worldwide and particularly the tropics lack continuous (long-term) measurements of glacier mass balance and/or climate variables. Nevertheless, as outlined above, particularly in these regions, implementation of adaptation measures to reduce adverse impacts of climate change requires decision and policy makers to be informed of regional/local glacier and climate trends. The science community is therefore challenged to provide estimates and assessments of trends and scenarios for regions with incomplete or weak data. Adequate approaches need to be developed and applied that can deal with incomplete data and allow for robust trend estimations of glacial and climatic changes and related impacts for specific regions.

This study focuses on the data-scarce area of the Cordillera Vilcanota (CV) in the southern Peruvian Andes. The CV is the second largest glacierized mountain range in Peru, and also comprises the Quelccaya Ice Cap (QIC), which is the largest tropical ice cap on Earth. The glaciers of the CV provide water for the relatively densely populated Cusco Region. For the CV, only very few long-term (decadal-scale) climate and glacier data are available. This is remarkable in view of its size and socio-economic importance (e.g. Vergara et al. 2007), and also in contrast to the Cordillera Blanca (central Peru), where several glacier measurement and observation programs were initiated during the past decades and are still running (e.g. Ames et al., 1989; Kaser et al., 2003).

In this study, we present an approach that allows providing a regional baseline for climate and glacier trends for the datascarce area of the CV. Past time series of observations and measurements from multiple sources, which are often made for reasons others than providing climatic baseline data, are collected, quality checked, homogenized and analyzed. The
Table 2. Loss of glacier area between 1962 and 2009 for QIC and Qori Kalis, an outlet glacier of the ice cap.

\begin{tabular}{rrrrr}
\hline Year & $\begin{array}{r}\text { Quelccaya Ice } \\
\text { Cap area } \\
\left(\mathrm{km}^{2}\right)\end{array}$ & $\begin{array}{r}\text { Percent of } \\
\text { initial area } \\
(\%)\end{array}$ & $\begin{array}{r}\text { Qori Kalis } \\
\text { glacier } \\
\text { area }\left(\mathrm{km}^{2}\right)\end{array}$ & $\begin{array}{r}\text { Percent of } \\
\text { initial } \\
\text { area }(\%)\end{array}$ \\
\hline 1962 & 57.5 & 100 & & \\
1975 & 56.2 & 98 & 0.92 & 100 \\
1985 & 55.7 & 97 & 0.84 & 91 \\
1991 & 47.9 & 83 & 0.76 & 83 \\
2000 & 45.9 & 80 & 0.59 & 64 \\
2004 & 45.4 & 79 & 0.58 & 63 \\
2006 & 44.2 & 77 & 0.53 & 58 \\
2008 & 42.8 & 74 & 0.49 & 53 \\
2009 & 42.8 & 74 & 0.49 & 53 \\
\hline
\end{tabular}

results eventually can serve to inform decision makers who are initiating climate change adaptation measures. The approach possibly also provides a blueprint for studies in other regions with similar challenges.

The paper starts with a description of the CV area (Sect. 2) and continues with a review of glacier and climate data from multiple sources available for this region, including inventories, satellite and GPR (ground-penetrating radar) data for the glaciers and station and Reanalyses data for the climate (Sect 3). The data are then prepared to serve as a baseline for consequent change assessments and trend analyses (Sects. 4 and 5). Finally in Sect. 6, the results are critically discussed and causally related.

\section{Study area: Cordillera Vilcanota - Quelccaya region}

The CV is located in southern Peru (about $14^{\circ} \mathrm{S}, 71^{\circ} \mathrm{W}$ ) in the Region Cusco (Fig. 1), at the eastern margin of the Andes where it marks the highest elevation above the Amazon Basin. The glacierized mountain range is arc-shaped, extending some $60 \mathrm{~km}$ east-west, and encompassing a high plateau region at about $4500 \mathrm{~m}$ a.s.l. and above. The most striking landscape feature of this Altiplano region is the Laguna Sibinacocha, a $15-\mathrm{km}$-long glacial lake that is used for hydropower generation. The highest peak of the mountain range is Nevado Ausangate (6384 m a.s.1.), and glacier tongues currently terminate at about 4700 to $5000 \mathrm{~m}$ a.s.l. (see Fig. 2). The QIC is the largest tropical ice cap on Earth and situated at the southeastern margin of the CV. It has been extensively studied in the context of climate-glacier interactions, starting in the 1970s (Hastenrath, 1978; Thompson et al., 1979). Thompson and colleagues drilled the first ice cores in tropical regions at Quelccaya and unfolded paleoclimate and glacier history (e.g. Thompson et al., 1984, 1985). With the steep mountain-type glaciers, the flat ice cap and several glaciers with proglacial lakes formed during the past years (like Qori Kalis), the CV encompasses different glacier types 

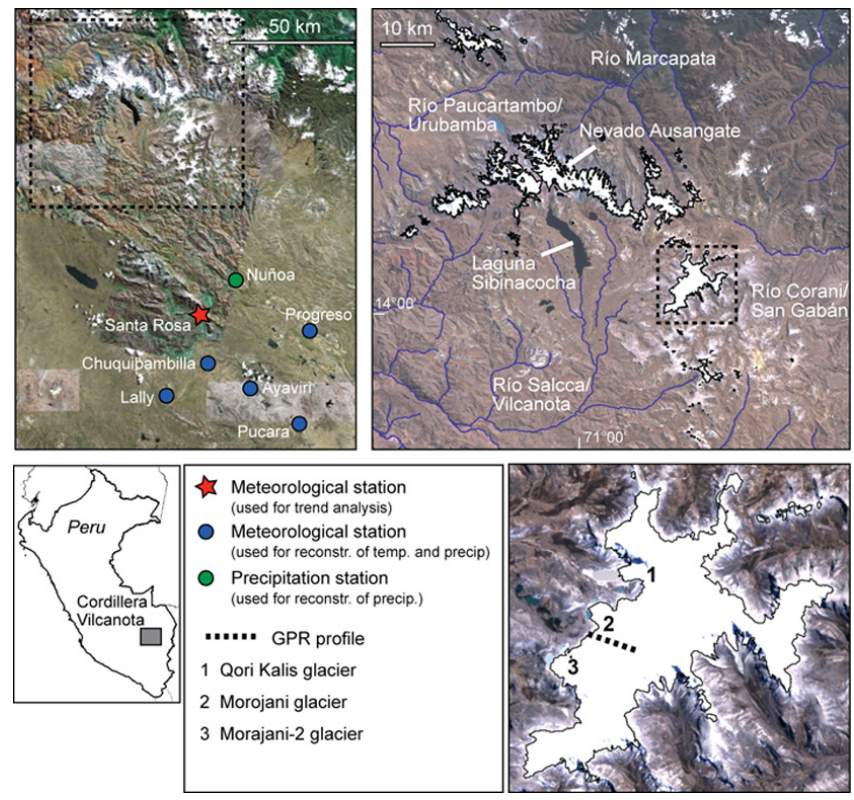

Fig. 1. Upper left: overview of study site; upper right: satellite view on the CV (Landsat-5 TM, 4 August 2006) with major river catchments indicated. The glacier outlines of 2006 are marked with a black line. Lower right: a close-up of the QIC with the dashed line indicating the location of the GPR profile taken in 2008.

with specific sensitivities, particularly in terms of length and thus area changes.

The drainage system of the CV is relatively complex, with glaciers draining into Río Paucartambo and later Río Urubamba and the Atlantic Ocean towards north and northwest, into Río Vilcanota, which feeds Laguna Sibinacocha and then continuous to Río Urubamba and the Atlantic towards south and northwest, Río Corani, San Gabán and the Atlantic towards northeast, and into Lago Titicaca towards southeast (Fig. 1). Socio-economically, Río Vilcanota, fed by the glaciers of $\mathrm{CV}$, is an important river in the region and used for hydropower, agriculture and household consumption.

There are very few glaciological studies available for the CV region. Morales-Arnao and Hastenrath (1999) provided an estimate of the glacier area for $1975\left(579 \mathrm{~km}^{2}\right.$, see also Sect. 6.1), and Mark et al. (2002) presented a paleoglaciological study for the western part of the cordillera. Huggel et al. (2003) assessed glacier changes between 1962 and 1999 but only for a smaller part of the mountain range, i.e. those glaciers draining into Río San Gabán towards northeast. They found that the glacier area has been reduced by as much as $53 \%$ during this period (from $52.8 \mathrm{~km}^{2}$ in 1962 to $27.6 \mathrm{~km}^{2}$ in 1999). A comprehensive study on recent glacier changes in the entire $\mathrm{CV}$, however, is still lacking.

The CV is situated in a climatologically complex zone, influenced by tropical and extra tropical upper level largescale circulation as well as synoptic-scale systems (Garreaud, 2009). During the wet season, the CV lies at the northern

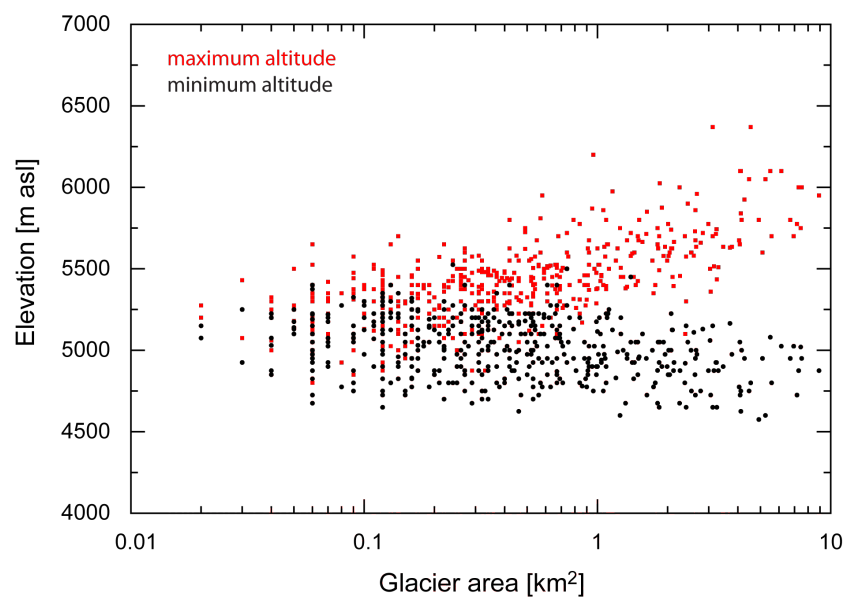

Fig. 2. Maximum and minimum altitude related to the glacier area for all glaciers in the CV in 1962 (based on the Peruvian glacier inventory).

boundaries of the Bolivian high and is thus mainly influenced by easterly flow that extends to $21^{\circ} \mathrm{S}$. During the dry season, westerly flow is predominate (Garreaud, 2009), particularly in the mid-tropospheric levels, which correspond with the elevation band of glaciers in these regions. Low-level flow transports most of the water vapour and thus controls precipitation, adding even more complexity. The high altitudes of the CV remain very dry during most of the year because of the low temperatures, low air density and high radiation. Only convective storms and moisture transported from the Amazon Basin by upper level easterlies lead to significant precipitation between December and March (Vuille et al., 2008; Falvey and Garreaud, 2009). The CV is situated in a region that is potentially also influenced by interannual variability patterns caused by the El Niño-Southern Oscillation (ENSO).

Given this climatological pattern, accumulation on the $\mathrm{CV}$ glaciers is mostly limited to austral summer months. Ablation processes (melt and sublimation) are active allyear round, with greatest ablation occurring also during the warmer wet season.

\section{Available observational data}

\subsection{Glacier data}

\subsubsection{Glacier inventory (aerial photographs)}

The national glacier inventory of Peru is the first region-wide catalogue of glaciers. It is based on aerial photographs and includes complete coverage of the CV for 1962 (Ames et al., 1989). The inventory provides information on geographic location, minimum and maximum glacier elevation, glacier width, length and area, and aspect for each glacier. In total, about 465 glaciers are on record in the inventory, showing an 
Table 3. Distribution of the aspect of the CV glaciers (based on the Peruvian glacier inventory, 1962).

\begin{tabular}{|c|c|c|c|c|c|c|c|c|}
\hline Aspect & North & $\begin{array}{l}\text { North- } \\
\text { East }\end{array}$ & East & $\begin{array}{r}\text { South- } \\
\text { East }\end{array}$ & South & $\begin{array}{l}\text { South- } \\
\text { West }\end{array}$ & West & $\begin{array}{l}\text { North- } \\
\text { West }\end{array}$ \\
\hline $\begin{array}{l}\text { Number of } \\
\text { glaciers }\end{array}$ & 53 & 57 & 43 & 69 & 64 & 80 & 50 & 49 \\
\hline
\end{tabular}

average minimum elevation of $5015 \mathrm{~m}$ a.s.l. and an average maximum elevation of $5427 \mathrm{~m}$ a.s.1., with standard deviations of $179 \mathrm{~m}$ and $244 \mathrm{~m}$, respectively (Fig. 2). Figure 2 furthermore shows that about $75 \%$ of the glaciers in 1962 were smaller than $1 \mathrm{~km}^{2}$ with their maximum altitude at around $5300 \mathrm{~m}$ a.s.1. The distribution of the exposition is relatively balanced, between $10 \%$ of the glaciers with an east aspect and $17 \%$ with a south-west aspect (Table 3).

\subsubsection{Satellite images}

For the present study Landsat-TM5 satellite images from 25 July 1985, 23 July 1996 and 4 August 2006 were acquired. The spatial resolution of the images is $30 \mathrm{~m}$. LandsatMSS images from this region exist from the mid-1970s but were not used here due to their reduced spatial resolution. The Landsat images from 1985, 1996 and 2006 represent favourable conditions for glacier mapping, and, together with the glacier inventory data, they allow for an assessment of glacier changes spanning about half a century.

For studying changes of the QIC at higher temporal resolution, additional Landsat images of 1975, 1991, and 2000, as well as ASTER images of 2004, 2006, 2008 and 2009, were used. These images were all taken during dry winter season between end of May and beginning of August.

As a topographic basis the SRTM-3 digital elevation model (DEM) at $90 \mathrm{~m}$ spatial resolution and the ASTER GDEM (global digital elevation map) at 90 and $30 \mathrm{~m}$ spatial resolution, respectively, were used. Vertical errors of SRTM are $\pm 16 \mathrm{~m}$ and $\pm 6 \mathrm{~m}$ for absolute and relative accuracy, respectively (Rabus et al., 2003). For the ASTER GDEM, a vertical error of $20 \mathrm{~m}$ at $95 \%$ confidence level is provided officially (ASTER Validation Team, 2009), but some studies have stressed the partly large errors of this DEM (Reuter et al., 2009).

\subsubsection{Ground-penetrating radar data}

For the current study also ground-penetrating radar (GPR) data were available. The GPR campaign was performed on the QIC in 2008 to assess the thickness of ice along a transversal profile (Figs. 1, 3). A Narod Geophysics type georadar transmitter with $5 \mathrm{Mhz}$ antennas and oscilloscope receiver was used. Data were collected at $10 \mathrm{~m}$ spacing along a single transect, and all points were georeferenced using a hand-held GPS receiver (accurate to about 5-10 m). The transect was approximately $2.3 \mathrm{~km}$ long, beginning at the ice cap summit and extending west towards the margin. A two-way travel time was calculated from the first reflection off the bed, and translated this travel time into an ice depth using a constant radar velocity of $0.168 \mathrm{~m} \mathrm{~ns}^{-1}$. Based on this velocity, a $1 / 4$ wavelength resolution of $8.4 \mathrm{~m}$ was calculated.

\subsection{Climate data}

\subsubsection{Meteorological stations}

The National Meteorological and Hydrological Service of Peru (SENAMHI) maintains a network of climate stations in the Cusco area. Several records start as early as 1965, but many stations were shut down in the meantime. Most have several major data gaps and a lot of the stations had even been out of order for several years during the politically unstable time in the 1980s. There are 30 stations located in the area of the CV at altitudes above $4000 \mathrm{~m}$ a.s.l., and several of them even above $4300 \mathrm{~m}$ a.s.1., nearly corresponding to the elevation of lowest glacier termini of the CV. All climate stations provide measured air temperature at 07/13/19h, minimum and maximum air temperature and daily or semi-daily precipitation sums. A small number of stations also provide other variables, including dew point, air pressure or wind velocity and direction. In addition, there are also some precipitation stations in the area.

\subsubsection{NCEP/NCAR Reanalysis}

In remote high-mountain regions, and generally in datascarce areas, global reanalyses are often the only continuous long-term data series available. They provide a continuous stream of three-dimensional fields of meteorological variables of the past through advanced data assimilation techniques of available observations (Bengtsson and Shukla, 1988). The space and time resolution of the generated data is determined by the model. It is furthermore independent of the number of observations, because areas void of observations are filled with dynamically and physically consistent model-generated information (Bengtson et al., 2004).

Here, we use the NCEP/NCAR Reanalysis 1 (see Kalnay et al., 1996), a global reanalysis with a horizontal resolution of T62 (about $210 \mathrm{~km}$ ), 28 vertical layers and with a record starting in 1948. The variables 6-hourly, daily and monthly averages are provided. For this study, we use the four grid boxes in the Cusco area $\left(10-15^{\circ} \mathrm{S}, 75-70^{\circ} \mathrm{W}\right)$ for air temperature. 
Table 4. Details for the five selected glaciers for the CV volume estimations for 2006.

\begin{tabular}{|c|c|c|c|c|c|c|c|c|}
\hline $\begin{array}{l}\text { Glacier } \\
\text { name }\end{array}$ & lat & long & $\begin{array}{r}\text { Area } \\
{\left[\mathrm{km}^{2}\right]}\end{array}$ & $\begin{array}{r}\text { Length } \\
{[\mathrm{km}]}\end{array}$ & Aspect & $\begin{array}{r}\text { Altitude } \\
\quad(\max )\end{array}$ & $\begin{array}{r}\text { Altitude } \\
(\text { min) }\end{array}$ & $\begin{array}{l}\text { Estimated avg. ice } \\
\text { thickness for entire } \\
\text { glacier }(\tau=1 \text { bar })\end{array}$ \\
\hline Ausangate3 & $13^{\circ} 47^{\prime}$ & $71^{\circ} 12^{\prime}$ & & & & & & \\
\hline 1962 & & & 4.54 & 3.9 & E & 6350 & 4800 & 24.8 \\
\hline 2006 & & & & 3.4 & & & 4900 & 22.9 \\
\hline No name & $13^{\circ} 47^{\prime}$ & $71^{\circ} 07^{\prime}$ & & & & & & \\
\hline 1962 & & & 0.19 & 0.6 & SE & 5400 & 5140 & 25.6 \\
\hline 2006 & & & & 0.45 & & & 5180 & 22.7 \\
\hline Huilayorc1 & $13^{\circ} 46^{\prime}$ & $70^{\circ} 59^{\prime}$ & & & & & & \\
\hline 1962 & & & 1.85 & 2.5 & SW & 6025 & 5050 & 28.5 \\
\hline 2006 & & & & 2.15 & & & 5100 & 25.8 \\
\hline Vela Aje & $13^{\circ} 47^{\prime}$ & $70^{\circ} 57^{\prime}$ & & & & & & \\
\hline 1962 & & & 1.49 & 1.7 & SW & 5700 & 5050 & 29.1 \\
\hline 2006 & & & & 1.2 & & & 5080 & 21.5 \\
\hline Paco Loma & $13^{\circ} 57^{\prime}$ & $70^{\circ} 51^{\prime}$ & & & & & & \\
\hline 1962 & & & 2.1 & 2.7 & W & 5450 & 5125 & 93.3 \\
\hline 2006 & & & & 2.35 & & & 5170 & 92.4 \\
\hline
\end{tabular}

\section{Methods}

\subsection{Glacier changes (area and volume)}

\subsubsection{Glacier area estimation}

Satellite images have been extensively used for the assessment of glacier areas. Successful results have been achieved with Landsat-TM (Thematic Mapper) data using the image rationing method by dividing band TM4 by TM5 (Paul et al., 2002; Raup et al., 2007). This method has also been applied in this study. For glacier mapping in the Cordillera Blanca (Peru), Racoviteanu et al. (2008) and Silverio and Jacquet (2005) used a Normalized Difference Snow Index (NDSI). In a methodological study on QIC, Albert (2002) showed that results from the NDSI and the TM4/TM5 method yield a difference of only $\sim 2 \%$ in glacier area. The error involved in automatic glacier mapping based on satellite data has been analyzed in several studies. A recent larger and systematic glacier mapping experiment reports errors of $<5 \%$ for debris-free glaciers such as in the CV (Paul et al., 2013).

Through all periods of glacier mapping, including the 1962 inventory, debris-covered glacier parts were not considered and thus consistency of methods is maintained over the analyzed period. Because of the typically steep slopes and high altitudes in the study area, debris cover is indeed expected to be of little importance in the CV. Further evidence for it is given through our extensive field surveys and detailed satellite image analyses.

\subsubsection{Glacier volume estimation}

Volume estimates for glaciers are difficult and fraught with considerable uncertainty, in particular for larger unmeasured regions. The method of Bahr et al. (1997) is the most widely used yet debated scaling method. It applies scaling laws between area and volume, based on calibration from measured glaciers. More recently, methods have been developed to compute ice thickness along glacier flow lines and volume estimates based on thickness interpolation algorithms (Farinotti et al., 2009; Linsbauer et al., 2012). These studies found that thickness estimates typically lie within an error range of $20-30 \%$.

Here, we used an approach based on Haeberli and Hoelzle (1995), using glacier inventory parameters to estimate ice thickness and volume. The average ice thickness $h_{f}[\mathrm{~m}]$ along the central flow line can be expressed as

$h_{f}=\frac{\tau}{f \cdot \rho \cdot g \cdot \sin \alpha}$

where $\tau=$ mean basal shear stress along the central flow line [bar]; $f=$ shape factor (taken as 0.8 for all glaciers); $\rho=$ density of ice $\left(900 \mathrm{~kg} \mathrm{~m}^{-3}\right.$, as an average value based on field data from other glaciers in Peru); $g=$ gravitational acceleration $\left(9.81 \mathrm{~m} \mathrm{~s}^{-2}\right) ; \alpha=$ average surface slope of the glacier. $\rho, f$ and $g$ can be considered constants while $\tau$ and $\alpha$ can vary among different glaciers. Basal shear stress is commonly considered to vary within 0.5 and 1.5 bar (Paterson, 1994), with values of $\sim 1$ bar as a first approximation and average for valley glaciers (Binder et al., 2009). Haeberli and Hoelzle (1995) presented an empirical relation between $\tau$ and $\Delta H$, the difference between maximum and minimum glacier elevation. However, this relationship was established primarily from a dataset of mid-latitude glaciers. Little is 


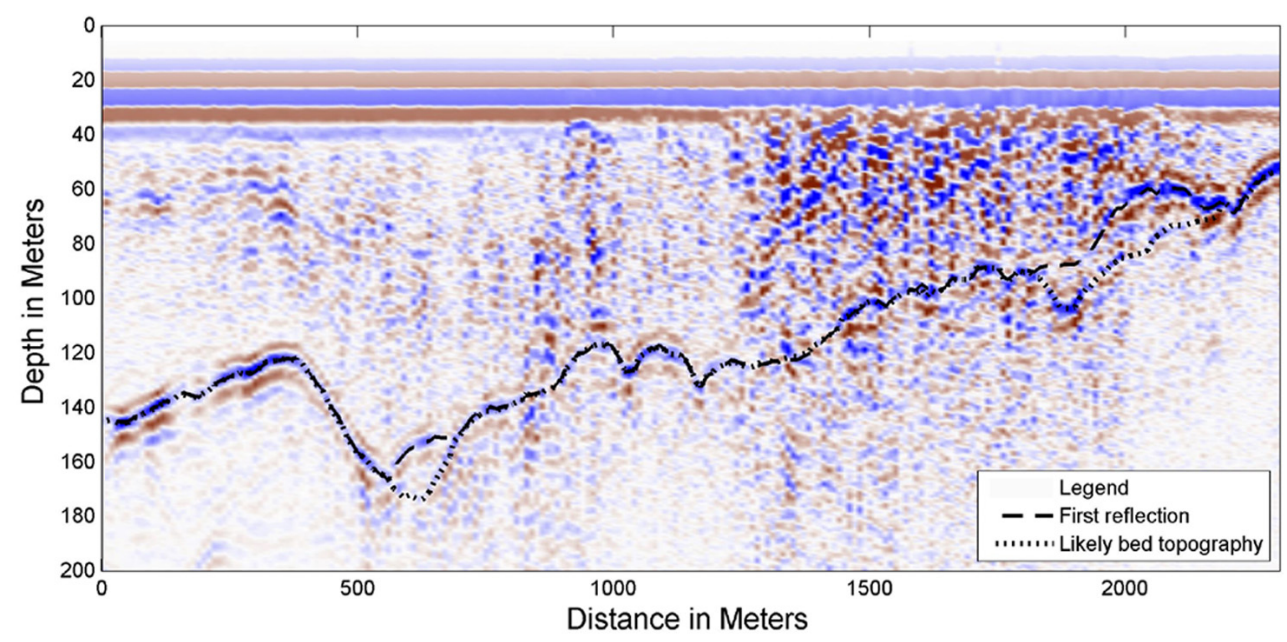

Fig. 3. Ground-penetrating radar (GPR) profile taken on QIC in 2008 along an east-west transect. The summit is to the left, and the ice margin to the right of the profile. The exact location is indicated in Fig. 1.

known about the basal shear stress values of tropical glaciers, although it is recognized that they are generally characterized by high mass balance gradients (Kaser and Osmaston, 2002; Huggel et al., 2003) and relatively small $\Delta H$. For the 1962 glacier inventory data of the $\mathrm{CV}$ region, we calculated a mean $\Delta H$ of $412 \mathrm{~m}$, with a standard deviation of $282 \mathrm{~m}$. Based on that and the relationship after Haeberli and Hoelzle (1995), we assessed a reasonable range of average basal shear stress of $0.8 \leq \tau \leq 1.2$ bar. For QIC, where we have GPR ice thickness measurements (see Sect. 3.1.3) available for validation, we performed several calculation runs with $0.8 \leq \tau \leq 1.2$ bar and found best agreement of modelled and measured ice thickness for $\tau=1.2$ bar (see also Sect. 5.1). However, to account for variations of mean basal shear stress on the different glaciers and to generally increase robustness of results, we also assessed ice thickness (and volume) by using $\tau=1$ bar. Eventually, to calculate the average ice thickness for the entire glacier based on the ice thickness $h_{f}$ along the central flow line, $h_{f}$ is multiplied by $\pi / 4$, assuming a semi-elliptical cross-sectional glacier geometry (Haeberli and Hoelzle, 1995). Ice volumes then simply result from calculated ice thickness and respective glacier areas.

The ice thickness estimates for 1962 were based on the corresponding glacier inventory data and the application of Eq. (1) for every single glacier, using $\tau=1$ bar and $\tau=1.2$ bar. The ice thickness estimates for 2006 were based on five glaciers (for details see Table 4), using the area information provided by the aforementioned satellite images. The ice thickness difference between 1962 and 2006 was calculated using Eq. (1). The average thickness reduction was found to be between 10 and $20 \%$ for this 40 -yr period. Accordingly, we applied a thickness-volume scaling using a thickness reduction of 10 to $20 \%$ and provide both reduction values for the 1 bar case and the 1.2 bar case to indicate a more realistic range of ice volumes for 2006.

For validation of the modelled ice thickness, we used ice thickness measurements from the GPR campaign on QIC in 2008 (Fig. 3). Measurements show an ice thickness maximum of approximately $150-170 \mathrm{~m}$ in an overdeepening near the summit (5670 $\mathrm{m}$ a.s.1.). Enhanced scattering is evident in the second half of the radar transect (beyond $\sim 1200 \mathrm{~m}$ horizontal), and may be the result of increased meltwater in the surface snowpack or underlying ice. Despite this increased scattering, bed reflections are apparent and show decreasing thickness towards the ice cap margin, reaching a minimum value of approximately $50 \mathrm{~m}$ at the end of the transect and the margin of the ice cap. Measurements in 1978/79 on QIC by Thompson et al. (1982) show maximum ice thickness of about $180 \mathrm{~m}$ in the saddle between the summit and the north domes, which support our results.

\subsection{Preparation of climate records for trend analyses}

Reliable climatic trend analyses require long-term, quality checked and homogenized climate time series to avoid trends caused by non-climatic factors (Begert et al., 2005).

In the frame of an ongoing climate change adaptation programme (PACC; Salzmann et al., 2009), a large number of the time series from the meteorological stations in the Cusco and Apurimac regions and the neighbouring areas have been quality checked (Schwarb et al., 2011). As aforementioned, most of the records, however, are not long enough or continuous to allow for reliable trend analyses. Therefore, we have reconstructed one continuous, long-term time series of one station to enable subsequent trend analyses for the $\mathrm{CV}$ area. For the reconstruction we have chosen the station Santa Rosa $\left(-14.6^{\circ} \mathrm{S},-70.8^{\circ} \mathrm{W}\right)$, which is located at $3940 \mathrm{~m}$ a.s.1., and among the closest stations to the 
Table 5. Correlation coefficient between the stations used to reconstruct Santa Teresa (1965-2009).

\begin{tabular}{llrrrrrr}
\hline & & Ayaviri & Chuquibambilla & Llally & Nunoa & Progreso & Pucara \\
\hline \multirow{2}{*}{ Monthly precip } & $r$ & 0.76 & 0.84 & 0.77 & 0.64 & 0.8 & 0.78 \\
& $R^{2}$ & 0.58 & 0.71 & 0.6 & 0.41 & 0.64 & 0.62 \\
\hline \multirow{2}{*}{ Monthly Mean Tx } & $r$ & 0.91 & 0.85 & 0.92 & & 0.88 & 0.85 \\
& $R^{2}$ & 0.83 & 0.73 & 0.85 & & 0.77 & 0.73 \\
\hline \multirow{2}{*}{ Monthly mean Ty } & $r$ & 0.98 & 0.96 & 0.96 & & 0.94 & 0.92 \\
& $\mathrm{R}^{2}$ & 0.98 & 0.92 & 0.91 & & 0.88 & 0.84 \\
\hline
\end{tabular}

CV. Data gaps (the years between 1965-1994 for air temperature, respectively between 1965-1970 and 1981-1989 for precipitation) have been reconstructed by using a number of nearby stations, situated within a radius of about $80 \mathrm{~km}$ from Santa Rosa (see Fig. 1): Ayaviri (3920 m a.s.1.), Chuquibambilla (3950 $\mathrm{m}$ a.s.1.), Llally (4190 m a.s.1.), Progreso (3965 m a.s.l.) and Pucara (3910 m a.s.l.). For precipitation, the station Nuñoa (4135 m a.s.l., at about $20 \mathrm{~km}$ distance from Santa Rosa) was additionally considered. From each of these stations, a linear correlation was calculated (Table 5) to find the best estimation value for Santa Rosa. A minimum of two observations per month (for air temperature), or three (for total precipitation sums), was used from the nearby stations. The arithmetic mean of all estimation values based on the linear model was then used as the reconstructed monthly air temperature mean and monthly total precipitation sum for the station Santa Rosa.

The NCEP/NCAR Reanalysis provides data at different pressure levels. The upper, glacierized parts of $\mathrm{CV}$ are located at an altitude of around $5600 \mathrm{~m}$ a.s.l. Because this is close to free-atmosphere conditions, here, we used the $500 \mathrm{hPa}$ atmospheric level corresponding to about 5850 m a.s.l.) of the NCEP/NCAR Reanalysis, instead of the NCEP/NCAR surface height fields at around 3500$4000 \mathrm{~m}$ a.s.l. for the CV area. Regarding record length, the NCEP/NCAR Reanalysis provides in principle data since 1948. However, before the Geophysical Year in 1958, only very few radiosonde measurements were taken in the Southern Hemisphere (e.g. Chen et al., 2008). Because radiosonde data are a primary input for the free atmosphere data in NCEP/NCAR Reanalysis, the homogeneity in the upperlevel troposphere in NCEP/NCAR Reanalysis must be questioned for the years before 1958 (Paltridge et al., 2009; Chen et al., 2008). Although we are aware that there is again a step towards increased homogeneity since 1979 due to the assimilation of satellite observations (Bengston et al., 2004; Vey et al., 2010), for the following analysis we will use the NCEP/NCAR Reanalysis between 1958, 1965, respectively, and 2009.

In principle, NCEP/NCAR Reanalysis also provides time series for specific humidity, a variable that influences the energy balance of the surface and thus tropical glaciers significantly (Kaser, 2001). However, here, we do not use
NCEP/NCAR Reanalysis for any trend analysis of specific humidity, (i) because of the abovementioned very limited radiosonde measurements with particular effects on specific humidity, and (ii) it is a level B variable (see Kalnay et al., 1996), indicating a high model- and a low observationdependence and thus low reliability on absolute values and particularly on trends.

These prepared continuous long-term time series were normalized before deriving the temporal trend using simple linear regression. We then calculate the p-value of the test with null hypothesis "no trend". If the null hypothesis is true, the temperature is distributed with $n-1$ degrees of freedom. The null hypothesis is rejected if the p-value is smaller than 0.05 .

\section{Results}

\subsection{Glacier changes (area and volume)}

Over the entire glacierized area of $\mathrm{CV}$, our results indicate that glaciers have changed only marginally between 1962 and 1985 (Table 1). Between 1985 and 1996, however, $100 \mathrm{~km}^{2}$ of ice has been lost, corresponding to a $23 \%$ reduction since 1985. The following $10 \mathrm{yr}$ until 2006 continued to show strong glacier retreat, yet with $10 \%$ at a lesser rate than during the previous $10 \mathrm{yr}$.

The more detailed data available for the QIC show a corresponding behaviour with the greater picture of the entire CV (Table 2). As for the rest of the mountain range, the QIC area did not significantly change between 1962 and 1985 . The strong glacier retreat started there also in the mid-1980s. The total glacier area of Quelccaya was reduced by $23 \%$ between 1985 and 2009, a somewhat lower value than for the overall CV. For Qori Kalis, an outlet glacier of the QIC, the available data (since 1975) also correspond with the general trend. However, its behaviour needs specific interpretation due to the influence by the formation of a proglacial lake (see Sect. 6.1).

In terms of ice volume loss, it is clear that it also must have been very strong over the past two decades, irrespective of the uncertainties involved in volume estimation. For 1962 , our estimates suggest an ice volume on the order of 
17 to $20 \mathrm{~km}^{3}$. For 2006 , the corresponding range is 9.2 to $12.4 \mathrm{~km}^{3}$, resulting in a volume loss of about $40-45 \%$. Since glacier area did not change much between 1962 and 1985, volume losses likewise must have taken place primarily since the mid-1980s.

For the north-western side of the ice cap with Morojani and Morojani-2 glaciers (Figs. 1, 3), GPR-measured average ice thickness is about $90 \mathrm{~m}$. For the corresponding sites on the two glaciers, from the summit of the ice cap to the glacier terminus, Eq. (1) indicates average ice thickness between $75 \mathrm{~m}$ and $99 \mathrm{~m}$, depending on glacier and shear stress value. As mentioned in Sect. 4.1.2, best agreement was found for $\tau=1.2$ bar.

\subsection{Climatic trends}

For air temperature, both station and NCEP/NCAR Reanalysis data show positive trends for the time window 19652009 (Figs. 4 and 5), with similar magnitudes but different $\mathrm{p}$-values at the significance level of 0.05 . Figure 4 shows the linear trends for minimum and maximum air temperature. A clear positive trend ( $\mathrm{p}$-value $=0.00004$ ) is found for monthly mean maximum air temperature (Fig. 4b, Table 6), while there is no or a weak trend only (p-value $=0.48$ ) for monthly mean minimum air temperature (Fig. 4a, Table 6). If we divide the time window into 1965-1980 (w1) and 1980-2009 (w2), related to the observed difference in the magnitude of ice loss before and after 1985, the minimum air temperature trend for $\mathrm{w} 1$ is found to be negative, while for $\mathrm{w} 2$ it is positive (Table 6). For maximum air temperature, this pattern is opposite, with a negative trend for $\mathrm{w} 1$ and a positive trend for w2.

Because of the distinctive seasonality (cold/dry and warm/wet) in the study area, which influences the glacier regime significantly, trends were also calculated for seasonal means. For maximum air temperature, we found positive trends (except for DJF) for all seasons (Fig. 5b, Table 6). The trend for minimum air temperatures (Fig. 5a, Table 6) shows only a slight increase during DJF and SON, no trend during MAM, and a negative trend for JJA.

The monthly mean air temperature trends from the NCEP/NCAR Reanalysis (Fig. 6, Table 6) show good agreement with the station data. There is a positive trend for all seasons, with absolute changes in the same ranges as for Santa Rosa station. Note, however, that the absolute changes for the NCEP/NCAR Reanalysis data span $12 \mathrm{yr}$ more (data since 1948).

For seasonal precipitation sums, the station Santa Rosa (Fig. 7, Table 7) shows slight negative linear trends for all seasons. However, only during SON the p-value is less than 0.005 . Changes for precipitation are thus not as obvious as for air temperature.

For specific humidity we did not use NCEP/NCAR Reanalysis data (as outlined in Sect. 4.2). Unfortunately, there are no reliable station data for specific humidity available in the region that could be used. On a larger geographical scale, however, several studies based on radiosonde, GPS or satellite observations indicate positive trends in specific humidity. Vuille et al. (2003) found positive humidity trends for the central Andes, in both the CRU dataset (1950-1994 and 1979-995) and the ECHAM4-T106 climate simulation for 1979-1998. Willett et al. (2010) found positive large-scale changes in surface humidity over land between 1973 and 1999 in HadCRUH and CMIP3. Furthermore, Dessler and Davis (2010) analyzed five different reanalyses and found in general (also for tropical mid- and upper troposphere) increasing atmospheric specific humidity, associated with increasing surface temperature. Based on these studies and physical consistency of an increase of specific humidity with increasing atmospheric air temperature, we assume here also a positive trend of specific humidity in the mid- and upper troposphere of the $\mathrm{CV}$ region.

\section{Discussion}

\subsection{Glacier area and volume change}

The observed changes and rates of changes in glacier area and volume of the CV are high, particularly since mid-1980s, where we found reductions of about $30 \%$ for area and of volume of about 40-45\% between 1985 and 2006. Between 1962 and 1985, glaciers were about stable as indicated by the numbers for these two years in Table 1 . The reported difference of $4 \mathrm{~km}^{2}$ is in the range of expected uncertainties when comparing results from different methods and base data, that is, from aerial photographs (glacier inventory, 1962) and satellite images for the years since 1985 . The relatively stable conditions between 1962 and 1985 are also supported by the findings for QIC, for which we have higher-resolution and more frequent data available. Although the sensitivity of a flat ice cap can be different compared to steep glaciers when the air temperature increases (cf. Sect. 6.3), this is not of great relevance here for the related period because of the relatively high altitude of the QIC (5670 m a.s.1.) compared to the average altitude of the CV glaciers (cf. Fig. 2). For Qori Kalis, our data start at 1975 (Table 2) and show a similar but somewhat stronger decreasing trend. Brecher and Thompson (1993) report an accelerating area and volume loss between 1963 and 1991 for Qori Kalis, and Thompson et al. (2006) provide evidence of continued acceleration until 2005. This stronger retreat pattern of the outlet glacier Qori Kalis compared to the ice cap, including an earlier onset of accelerated glacier retreat, is likely to some part related to the formation of a proglacial lake, the different hypsometries (Mark et al., 2002) and to some part to the lower elevation of the margins of QIC.

Our results on glacier changes in the $\mathrm{CV}$ corroborate findings from other glacierized cordilleras in Peru, but also add new insights. The Cordillera Blanca is by far the most 


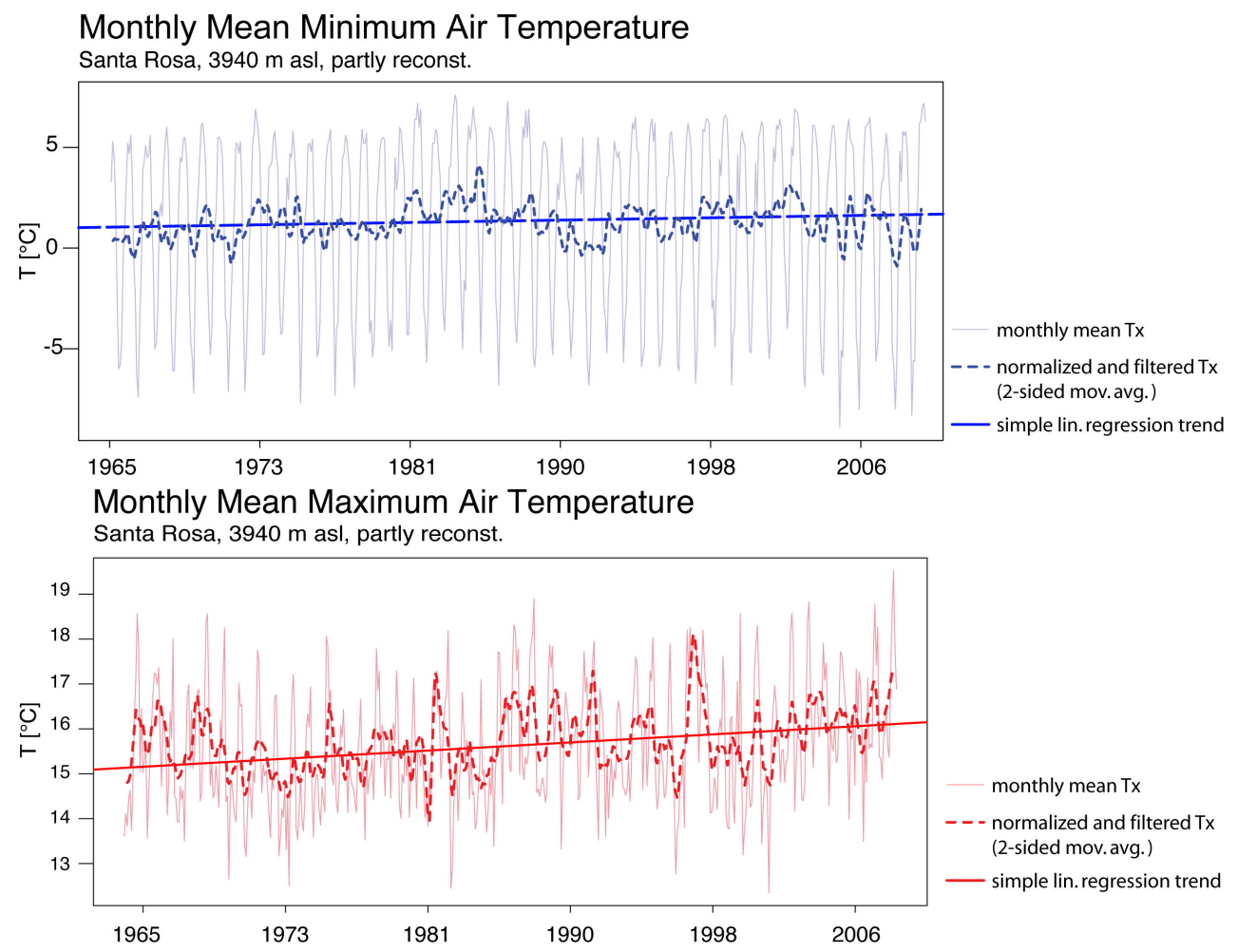

Fig. 4. Monthly minimum (a) and maximum (b) air temperature for Santa Rosa station. Dashed trend lines indicate where the p-value is above the significance level 0.05 (cf. also Table 4).

a)

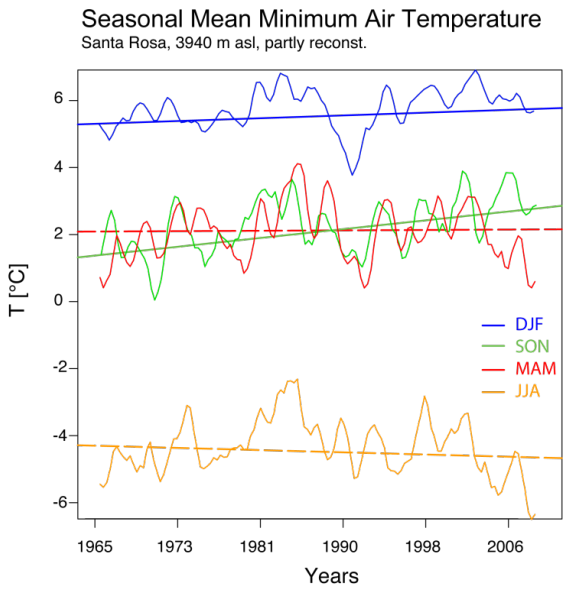

b)

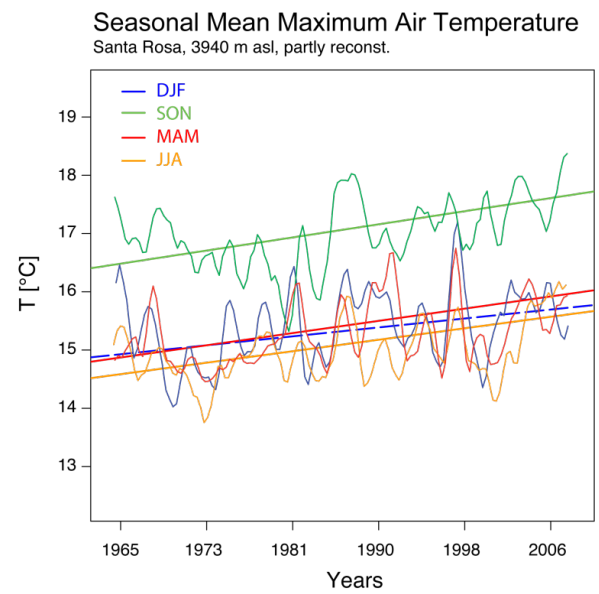

Fig. 5. Seasonal mean minimum (a) and maximum (b) air temperature for Santa Rosa station. Shown are the normalized and fitted (2-sided moving average) time series. Dashed trend lines indicate where the p-value is above the significance level 0.05 (cf. also Table 6).

studied glacierized cordillera of Peru, both historically and at present. Consistent with our results for $\mathrm{CV}$, studies from the Cordillera Blanca reveal little change between 1970 and 1986 (Georges, 2004; Silverio and Jacquet, 2005). For the same region, Baraer et al. (2012) report an annual reduction of glacier extent between 1990 and 2009 of about $0.81 \%$.
Studies in the Cordillera Blanca furthermore indicate that the 1930s and 1940s were characterized by significant glacier loss, resulting in growth and formation of many glacier lakes, with severe disasters due to lake outburst floods (Carey, 2005). There are no corresponding documents available for this period for the $\mathrm{CV}$, probably due to its remote location. 
Table 6. Trend magnitude per decade and p-value for seasonal and annual monthly minimum, maximum and mean air temperature for the period 1965-2009 (w) and for the period 1965-1980 (w1) and 1980-2009 (w2).

\begin{tabular}{|c|c|c|c|c|c|c|}
\hline & \multicolumn{2}{|c|}{$\begin{array}{l}\text { Tn Santa Rosa station } \\
\text { (partly reconstr.) }\end{array}$} & \multicolumn{2}{|c|}{$\begin{array}{l}\text { Tx Santa Rosa station } \\
\text { (partly reconstr.) }\end{array}$} & \multicolumn{2}{|c|}{$\begin{array}{c}\text { Tm air temp. NCEP/NCAR } \\
\text { Reanalysis }(500 \mathrm{hPa})\end{array}$} \\
\hline & p-value & $\begin{array}{l}\text { trend magnitude } \\
\qquad\left[{ }^{\circ} \mathrm{C} \mathrm{dec}^{-1}\right]\end{array}$ & p-value & $\begin{array}{l}\text { trend magnitude } \\
\qquad\left[{ }^{\circ} \mathrm{C} \mathrm{dec}^{-1}\right]\end{array}$ & p-value & $\begin{array}{l}\text { trend magnitude } \\
\qquad\left[{ }^{\circ} \mathrm{C} \mathrm{dec}^{-1}\right]\end{array}$ \\
\hline $\mathrm{DJF}(\mathrm{w})$ & 0.005 & 0.013 & 0.056 & 0.013 & 0.00025 & 0.021 \\
\hline MAM (w) & 0.95 & 0.0012 & 0.001 & 0.018 & 0.0018 & 0.017 \\
\hline JJA (w) & 0.46 & -0.0067 & 0.0015 & 0.017 & 0.00024 & 0.022 \\
\hline SON (w) & 0.014 & 0.027 & 0.001 & 0.019 & 0.00033 & 0.018 \\
\hline All year (w) & 0.48 & 0.008 & 0.00004 & 0.018 & & \\
\hline All year (w1) & 0.72 & 0.021 & 0.18 & -0.024 & & \\
\hline All year (w2) & 0.4 & -0.02 & 0.005 & 0.023 & & \\
\hline
\end{tabular}

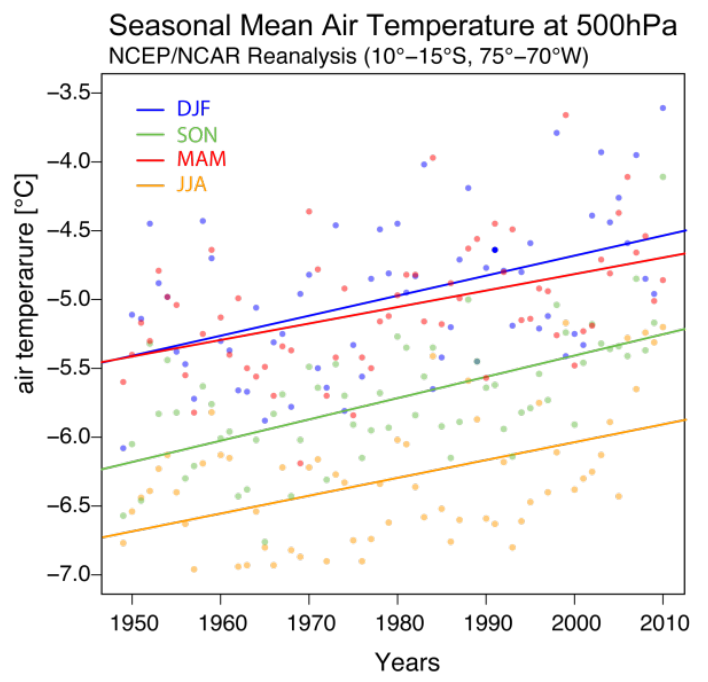

Fig. 6. Linear trends for mean seasonal air temperature at $500 \mathrm{hPa}$ level from NCEP/NCAR Reanalysis for the period 1958-2009. Dashed trend lines indicate where the p-value is above the significance level 0.05 (cf. Table 6).

For both cordilleras of Peru, the strong recent glacier shrinkage likely started in the second half of the 1980's. The glacier shrinkage in the CV appears to have been somewhat stronger than in the Cordillera Blanca. While a reduction in area of 12-22\% between 1970 and 2003 is reported for the Cordillera Blanca (Racoviteanu et al., 2008), corresponding values from the CV are approximately $30 \%$ higher. It should be noted that there is one reference (Morales-Arnao and Hastenrath, 1999) that indicates for the $\mathrm{CV}$ a glacier area of $579 \mathrm{~km}^{2}$ for 1975 . This is much higher than our relatively constant values found between 1962 and 1985 (cf. Table 1). However, these deviations are likely due to difficulties that arise when comparing different studies based on unofficial boarders. Here, the deviation could result either from a differently defined spatial domain of the $\mathrm{CV}$ area in the two studies, i.e. the definition of glaciers that are included in the as-
Table 7. Precipitation sums, Santa Rosa station (partly reconstr.) for the period 1965-2009.

\begin{tabular}{lrr}
\hline year & $\mathrm{p}$-value & trend magnitude $\left[\mathrm{mm} \mathrm{dec}^{-1}\right]$ \\
\hline DJF & 0.09 & -18.75 \\
MAM & 0.15 & -12.8 \\
JJA & 0.15 & -3.8 \\
SON & 0.043 & -16 \\
\hline
\end{tabular}

sessment, or due to reduced accuracy of the lower-resolution Landsat-MSS satellite images used for the study in 1975.

The changes and rate of changes found for $\mathrm{CV}$ are also high compared for example to numbers from the European Alps. While we found a reduction of area of about $30 \%$ and of volume of about 40-45\% between 1985 and 2006 for CV, Zemp et al. (2006) report for the period between 1975 and 2000 a reduction of glacier area of about $22 \%$ and of volume of about $30 \%$ for the European Alps.

In summary, based on the available data for the CV and the numbers reported from other areas, the $\mathrm{CV}$ encountered similar and uniform changes but at the upper end of the reported ranges. Possible relations to specific climatic forcing in the CV area are further discussed in Sect. 6.3.

There are very few glacier volume change estimates available for other mountain ranges in Peru. Mark and Seltzer (2005) assessed volume changes for three individual glaciers in the Cordillera Blanca between 1962 and 1999. Their estimates are broadly consistent with ours. For Nevado Coropuna, an ice-capped volcano $270 \mathrm{~km}$ southwest of the $\mathrm{CV}$, in a much drier climate, Peduzzi et al. (2010) estimated an ice volume of $4.62 \mathrm{~km}^{3}$ for the 2000 s with an average ice thickness of $81 \mathrm{~m}$ and an error margin of about $\pm 20 \%$, using a statistical relation between ice thickness, elevation, slope and aspect. While a reduction of glacier area of $60 \%$ was mapped for the period 1955-2008, there was a $18 \%$ loss estimated for the corresponding volume. However, the glacier area reported by Peduzzi et al. (2010) for Cordillera Coropuna in $1955\left(122.7 \mathrm{~km}^{2}\right.$ ) is probably about $40 \mathrm{~km}^{2}$ (or $48 \%$ ) 
too large due to strong snow cover on aerial photographs (P. Peduzzi and W. Silverio, personal communication, 2011). According to the data from Peru's glacier inventory (Ames et al., 1989), the area of the glaciers on Nevado Coropuna was $82 \mathrm{~km}^{2}$ in 1962 (see also Racoviteanu et al., 2007). Peduzzi et al. (2010) furthermore indicate a glacier area of $80.1 \mathrm{~km}^{2}$ for 1980, followed by strong retreat resulting in an area of $65.5 \mathrm{~km}^{2}$ by 1996 . Hence, by correcting the figures for the 1950s and 1960s for Coropuna from 122 to $82 \mathrm{~km}^{2}$, a consistent pattern of glacier changes from north to south Peru is found, which shows that glacier areas were relatively stable between the 1960s and 1980s followed by a period of strong glacier retreat that continues until today.

It is widely recognized that regional glacier volume estimates are associated with large uncertainties, due to the inability to directly and precisely measure the ice dimensions, and the need to extrapolate ice thickness by using semiempirical formula. Accordingly, we aimed at making the assumptions used explicit. In our modelling approach, the basal shear stress is a sensitive parameter for the volume estimates. Yet, we evaluated our modelled shear stress using GPR ice thickness measurements on the QIC to constrain a reasonably appropriate value. Confidence in our estimates furthermore is given by a recent study on Jostedalsbreen ice cap in Norway, where shear stress values found are similar to ours on Quelccaya (Meister, 2010). To our knowledge, there are no other references of estimates of basal shear stress for tropical glaciers available, and, consequently, a range of uncertainty of about $20 \%$ needs to be considered. We therefore used different values to indicate the likely range of ice volume.

For a comparison of methods, we calculated the volumes of each glacier by using the volume-area scaling approach by Bahr et al. (1997). The resulting total volume for CV is $20.1 \mathrm{~km}^{3}$ for the Bahr method (for 1962), which compares very well to $20.4 \mathrm{~km}^{3}$ based on the previously presented method, using a basal shear stress of 1.2 bar (Eq. 1). The small difference between the two methods by only $1.5 \%$ should not be overemphasized, but generally adds confidence to our volume estimates.

In terms of error estimates for volume calculation, recent modelling studies computing ice thickness along glacier flow lines for mid-latitude glaciers indicate error ranges of 20$30 \%$ (Farinotti et al., 2009; Linsbauer et al., 2012). Another approach using measured length changes showed that modelled glacier volumes may be within a $30 \%$ error margin in a reasonable case, but in less optimal cases may vary as much as several factors (Lüthi et al., 2010).

In summary, we recognize that our absolute volume estimates for each time step are probably subject to uncertainties in the range of $20-30 \%$, but comparison with other methods such as the one from Bahr et al. (1997) indicates that the numbers are reasonable. Furthermore, it can be stated that relative ice volume change between the time periods is robust and plausible given the vigorous loss in area.

\subsection{Climatic trends}

Based on the data used in our study, there is a linear air temperature increase found since the 1950s and 1960s, with greater changes for maximum than for minimum air temperature, and a slight negative trend for precipitation. These findings correspond with results from other studies in this region (Vuille et al., 2003; Francou et al., 2003). However, compared to air temperature trends in other mountain regions such as the European Alps (Begert et al., 2005; Auer et al., 2007), the trends for the $C V$ are relatively small, nevertheless consistent with continental-scale analyses (IPCC, 2007).

The two time windows w1 and w2 (see Sect. 5.2, Table 6) for which we found opposing trends for air temperature differ clearly in terms of ENSO events. During w2, unlike through w1, two major ENSO events (1982/83 and 1997/98) took place. Based on our data, there is, however, no clear and/or synchronous pattern found during these two events in the CV region, letting us assume that ENSO events do not significantly affect air temperature trends in the $\mathrm{CV}$ region.

In order to account for data inhomogeneity and uncertainty inherent to our remote setting, and to reduce uncertainties, we used a multi-data-source approach and pre-processed the data adequately prior to their use. The general agreement in the magnitude and of the trends found for climate variables from different sources makes these trends plausible. As such, this study presents probably the most convincing regional estimates for the $\mathrm{CV}$ area, and to our knowledge, there are no better observations available than used in this study. ERA-40 reanalysis (Uppala et al., 2005), another well-known global reanalysis was not included in this study, because the ERA-40 is known to be generally less homogeneous than the NCEP-NCAR Reanalysis (e.g. Chen et al., 2008).

With the Santa Rosa meteorological station, which is about $80 \mathrm{~km}$ away from the CV, we have chosen among the closest stations to the CV. Since in the tropics air temperature is relatively persistent within horizontal distances (Sobel et al., 2001), we consider a distance of $80 \mathrm{~km}$ reasonable. The vertical distance between the station and the glacier terminus can be compensated by using the regionally derived lapse-rate value $\left(0.5^{\circ} \mathrm{C} 100 \mathrm{~m}^{-1}\right)$ reported by Urrutia and Vuille (2009).

\subsection{Relation between observed climatic trends and glacier changes}

The relatively slightly negative trend of precipitation and the moderate increase of air temperature found for the CV cannot in full explain the observed substantial ice losses. In the following, we therefore try to further discuss and complete the observed changes.

Area and volume changes of a glacier are related to climatic variables through its energy and mass balance. Negative changes in the mass balance of a glacier result either from increased ablation or decreased accumulation, which 
are mainly determined by precipitation and air temperature. For the tropical and subtropical Andes, Francou et al. (2003) concluded that precipitation and cloud cover changes were minor in the 20th century and it is thus unlikely that decreased accumulation explains the observed glacier retreat in the region. In contrast, they found a positive trend for air temperature and conclude that glacier retreat is mainly caused by increased ablation, rather than decreased accumulation. The trends that are indicated by our data for $\mathrm{CV}$ are consistent with these conclusions, and the slight decrease in precipitation we note over the past decades (Fig. 7) is unlikely to account for all the glacier retreat. In the following, we will thus turn our discussion to the effects of climatic changes on the ablation processes.

The most important terms able to significantly influence the surface energy balance of a tropical glacier are net solar radiation $\left(Q_{\mathrm{R}}\right)$, net longwave radiation $\left(Q_{\mathrm{L}}\right)$ and, to a lesser extent, the turbulent sensible $\left(Q_{\mathrm{H}}\right)$ and latent heat fluxes $\left(Q_{\mathrm{LE}}\right)$, as measured by Hastenrath (1978) for QIC and by Sicart et al. (2005) for Zongo glacier in Bolivia. Air temperature is typically highly correlated to various components of the energy balance. However, as the measurements by Sicart et al. (2008) show, air temperature measurements in the tropics are poorly correlated to net shortwave radiation, particularly for short time steps, and is thus not an ideal index for the energy balance. In relation with $Q_{\mathrm{R}}$, albedo is another important factor. On tropical high-elevation glaciers, there are different factors that can modify albedo, including changes in precipitation in relation with air temperature (rain or snow) and factors like debris cover, dust and soot. The latter factors are of minor importance at the $\mathrm{CV}$ due to its high altitude, and the absence of high rock faces around the glaciers. Moreover, to our knowledge there is no specific long-term albedo information available for the CV. For precipitation only a very slight trend is observed at the operational meteorological stations of SENAMHI (Fig. 7). However, there is a clear air temperature increase observed in both datasets. Using the lapse-rate values of Urrutia and Vuille (2009) to translate the upper-air temperature data into glacier terminus elevation, the mean temperature stays well below $0^{\circ} \mathrm{C}$, and maximum air temperature is well above $0^{\circ} \mathrm{C}$ (while minimum air temperature shows no clear trend). Consequently, it can be inferred that the relation between liquid and solid precipitation arriving at the glacier surface has not changed during the past decades and the average albedo has not or only moderately been modified. Therefore, it can be assumed that most of the precipitation still falls in the form of snow, and related average albedo is thus only moderately changed by the observed air temperature increase. Nevertheless, Bradley et al. (2009) report an increase in freezing level heights (based on daily maximum air temperatures only) for the QIC, implying that air temperature increase in the future could have a more important effect on albedo and thus on $Q_{\mathrm{R}}$, as the snow line moves upwards. Particularly the plane QIC with an elevation maximum of about $5670 \mathrm{~m}$ a.s.l. would be highly sen-

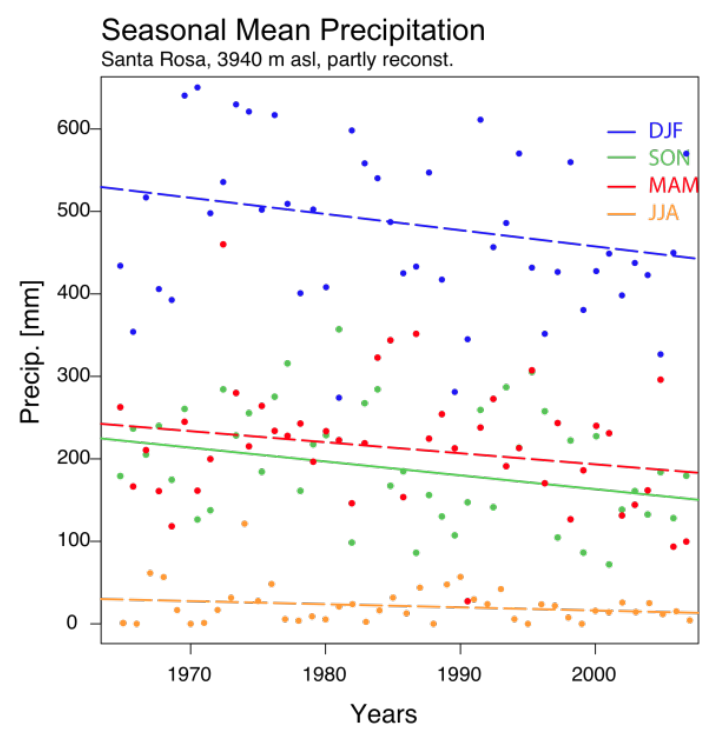

Fig. 7. Linear trend for seasonal precipitation sums from the station Santa Rosa. Dashed trend lines indicate where the p-value is above the significance level 0.05 (cf. Table 7).

sitive to an upward-move with a rapid impact on the entire QIC area once the freezing threshold value is crossed.

In addition to the global mean air temperature increase during the last $150 \mathrm{yr}$, a significant increase has also been observed for water vapour, another and even more effective greenhouse gas (IPCC, 2007). As outlined in Sect. 5.2, it is very likely that water vapour has increased over the $\mathrm{CV}$ region consistent with positive large-scale trends (Vuille et al., 2003; Dessler and Davis, 2010; Willett et al., 2010). An increase of $q$ can significantly influence $Q_{\mathrm{LE}}$, which would attenuate the typically negative latent heat flux on high altitude tropical glaciers, and in turn make more energy available for melting (e.g. Wagnon et al., 1999). An increase in $q$ leads additionally to an increase in incoming longwave radiation (Ruckstuhl et al., 2007; Ohmura, 2001), which leads often to an increase in air temperature near the surface. Depending on the effective quantity of specific humidity available, an increase in longwave radiation can lead to melting or sublimation and thus to a mass loss of glacier ice. Therefore, we argue here that the increase in water vapour during the past decades exerted an important control on the massive ice loss observed in the $\mathrm{CV}$, particularly before 2000 . This argument is strengthened by the fact that tropical glaciers in general respond relatively rapidly to changes in atmospheric conditions (typically within a few years) because of their usually small sizes (e.g. Bahr et al., 1998). This rapid response time can furthermore also explain the more rapid retreat of glaciers as observed since the 1980's. 


\section{Conclusions and perspectives}

In this study we presented a multi-sources approach allowing the generation of a data baseline for regional glacier and climatic trend analyses in a data-scarce mountain area. We assimilated and analyzed a comprehensive data collection of glacier and climate observations for the $\mathrm{CV}$ region (southern Peruvian Andes), which exemplifies a remote, data-scarce mountain region, with major socio-economic importance due to its water resource. For such regions, there is an increasing demand by decision and policy makers for information about climatic changes, related impacts and future scenarios. Such demands will even increase in the future with regard to ongoing international efforts (e.g. Adaptation Fund (AF) and the new Green Climate Fund (GCF) under the United Nations Framework Convention on Climate Change, UNFCCC) for developing and implementing adequate adaptation measures, on regional and local levels.

The trends we found in our study are generally in line with continental and regional trends from other studies. Glacier ice reduction is slightly higher than in other cordilleras in the region and higher than, e.g. in the European Alps. At the same time, air temperature trends are positive, but weaker than for Europe, while precipitation sums remained about stable. Based on our data, there is no clear relation to ENSO events visible for the CV area. Furthermore, an increase of specific humidity for the area of CV is very likely, which may explains part of the observed substantial ice loss.

Assuming that the observed climatic trends will continue in the future in the $\mathrm{CV}$ region, the impacts would affect the four seasons differently as outlined in the following and with implications to be considered in any adaption strategy plans: Austral winter (JJA), generally a very dry season, would not be much influenced by increasing $q$, because the large positive radiation balance would be cancelled out by the large negative longwave radiation. For austral spring (SON) and autumn (MAM) any projection remains uncertain. In case precipitation events become more frequent in future, it will be critical whether they hit the ground as rain or as snow because of the large albedo difference and its impact on the mass balance. With increased humidity, longwave energy loss would generally be small. Austral summer (DJF) is characterized by large precipitation events. Whether precipitation will increase or decrease in future in the central Andes is difficult to assess. Minvielle and Garreaud (2011) show in their study an inconsistent picture for MIP3 projections, but find a decreasing trend after applying statistical downscaling based on a zonal wind-precipitation relationship. Kitoh et al. (2011) analyzed precipitation changes over South America using a very high resolution $(20 \mathrm{~km})$ GCM (MRIAGCM). Their projections show an increase in precipitation for the central Andes. With a trend towards even moister austral summers, the longwave radiation balance would be even more often balanced, and in combination with clear-sky conditions from time to time (which is possible with convective regimes), shortwave radiation would be favoured as melt energy and cause an increase in melt.

These complex interactions between climate and glaciers also show clearly the need for long-term in situ measurements in order to better understand the effective ongoing processes and to provide a data baseline that allows for reliable projections of future glacier and runoff evolution. Therefore, in July 2010, a new glacier monitoring network was initiated on two glaciers in the $\mathrm{CV}$, within the frame of the PACC project. Moreover, in May 2011, on one of the glaciers a climate station was installed by SENAMHI. More specific insights on local climate and glacier evolution at CV are thus to be expected in the forthcoming years.

Acknowledgements. This study was mostly funded by the PACC, a program financed by the Swiss Development Agency (SDC). We also acknowledge the use of data from SENAMHI, Global Land Cover Facility (GLCF) and United States Geological Survey (USGS). Furthermore we thank A. Linsbauer, H. Frey, F. Paul (all University of Zurich, Switzerland) and T. Meierbachtol (University of Montana, USA) for comments and support with radar processing, and glacier mapping and volume estimates. We thank the two anonymous reviewers and the editor A. Klein for their valuable comments, which improved the manuscript considerably.

Edited by: A. Klein

\section{References}

Albert, T. H.: Evaluation of remote sensing techniques for ice-area classification applied to the tropical Quelccaya ice cap, Peru, Polar Geography, 26, 210-226, 2002.

Ames, A., Dolores, S., Valverde, A., Evangelista, C., Javier, D., Ganwini, W., and Zuniga, J.: Glacier inventory of Peru, Part I, Hidrandina S.A. Huaraz, Peru, 1998.

ASTER Validation Team: ASTER global DEM validation summary report, Validation Team: METI/ERSDAC, NASA/LPDAAC, USGS/EROS, 2009: ASTER Global DEM Validation, Summary Report, available at: https://lpdaac.usgs.gov, 2009.

Auer, I., Böhm, R., Jurkovic, A., Lipa, W., Orlik, A., Potzmann, R., Schöner, W., Ungersböck, M., Matulla, C., Briffa, K., Jones, P., Efthymiadis, D., Brunetti, M., Nanni, T., Maugeri, M., Mercalli, L., Mestre, O., Moisselin,. J-M., Begert, M., MüllerWestermeier, G., Kveton, V., Bochnicek, O., Stastny, P., Lapin, M., Szalai, S., Szentimrey, T., Cegnar, T., Dolinar, M., GajicCapka, M., Zaninovic, K., Majstorovic, Z., and Nieplova, E.: HISTALP - historical instrumental climatological surface time series of the Greater Alpine Region, Int. J. Clim., 27, 17-46, 2007.

Bahr, D. B. Meier, M. F., and Peckham, S. D.: The physical basis of glacier volume-area scaling, J. Geophys. Res, 102, 355-362, 1997.

Bahr, D. B., Pfeffer, W. T., Sassolas, C., and Meier, M. F.: Response time of glaciers as a function of size and mass balance: I. Theory, J. Geophys. Res., 103, 9777-9782, 1998.

Baraer, M., Mark, B., McKenzie, J. Condom, T., Bury, J., Huh, K., Portocarrero, C., Gomez, J., and Rathay, S.: Glacier recession 
and water resources in Peru's Cordillera Blanca, Ann. Glaciol., 58, 134-150, 2012.

Barnett, T. P., Adam, J. C., and Lettenmaier, D. P.: Potential impacts of a warming climate on water availability in snow-dominated regions, Nature, 438, 303-309, 2005.

Bengtsson, L. and Shukla, J.: Integration of Space and In Situ Observations to Study Global Climate Change, Bull. Amer. Meteor. Soc, 69, 1130-1143, 1988.

Bengtsson, L., Hagemann, S., and Hodges, K. I.: Can climate trends be calculated from reanalysis data?, J. Geophys. Res., 109, D11111, doi:10.1029/2004JD004536, 2004.

Begert M., Schlegel T., and Kirchhofer W.: Homogeneous Temperature and Precipitation Series of Switzerland from 1864 to 2000, Int. J. Clim., 25, 65-80, 2005.

Binder, D., Bruckl, E., Roch, K. H., Behm, M., Schoner, W., and Hynek, B.: Determination of total ice volume and ice-thickness distribution of two glaciers in the Hohe Tauern region, Eastern Alps, from GPR data, Ann. Glaciol., 50, 71-79, 2009.

Bradley, R. S., Vuille, M., Diaz, H. F, and Vergara, W.: Climate Change: Threats to Water Supplies in the Tropical Andes, Science, 312, 1755-1756, doi:10.1126/science.1128087, 2006.

Bradley, R. S., Keimig, F. T., Diaz, H. F., and Hardy, D. R.: Recent changes in freezing level heights in the Tropics with implications for the deglacierization of high mountain regions, Geophys. Res. Lett., 36, L17701, doi:10.1029/2009GL037712, 2009.

Brecher, H. H. and Thompson, L. G.: Measurement of the retreat of Qori Kalis Glacier in the Tropical Andes of Peru by terrestrial photogrammetry, Photogramm. Eng. Rem. S., 59, 1017-1022, 1993.

Carey, M.: Living and dying with glaciers: people's historical vulnerability to avalanches and outburst floods in Peru, Global Planet. Change, 47, 122-134, 2005.

Chen, J., Del Genio, A. D. Carlson, B. E., and Bosilovich, M. G.: The spatiotemporal structure of twentieth-century climate variations in observations and reanalyses, Part I: Long-term trend, J. Climate, 21, 2611-2633, doi:10.1175/2007JCLI2011.1, 2008.

Chevallier, P., Pouyoud, B., Suarez, W., and Condom, T.: Climate change threats to environment in the tropical Andes: glaciers and water resources, Reg. Environ. Change, 11, 179187, doi:10.1007/s10113-010-0177-6, 2011.

Dessler, A. E. and Davis, S. M.: Trends in tropospheric humidity from reanalysis systems, J. Geophys. Res., 115, D19127, doi:10.1029/2010JD014192, 2010.

Dessler, A. E., Zhang, Z., and Yang, P.: Water-vapor climate feedback inferred from climate fluctuations, 2003-2008, Geophys. Res. Lett., 35, L20704, doi:10.1029/2008GL035333, 2008.

Farinotti, D., Huss, M., Bauder, A., Funk, M., and Truffer, M.: A method to estimate the ice volume and ice-thickness distribution of alpine glaciers, J. Glaciol., 55, 422-430, 2009.

Falvey, M. and Garreaud, R.: Regional cooling in a warming world: Recent temperature trends in the SE Pacific and along the west coast of subtropical South America (1979-2006), J. Geophys. Res., 114, D04102, doi:10.1029/2008JD010519, 2009.

Francou, B., Vuille, M., Wagnon, P., Mendoza, J., and Sicart, J. E.: Tropical climate change recorded by a glacier of the central Andes during the last decades of the 20th century: Chacaltaya, Bolivia, $16^{\circ} \mathrm{S}$, J. Geophys. Res., 108, 4154, doi:10.1029/2002JD002959, 2003.
Garreaud, R.: The Andes climate and weather, Adv. Geosci., 7, 1-9, 2009, http://www.adv-geosci.net/7/1/2009/.

Georges, C.: 20th-century glacier fluctuations in the Tropical C. Blanca, Peru, Arctic, Antarctic, and Alpine Research, 36, 100107, 2004.

Haeberli, W. and Hoelzle, M.: Application of inventory data for estimating characteristics of and regional climate-change effects on mountain glaciers: a pilot study with the European Alps, Ann. Glaciol., 21, 206-212, 1995.

Hastenrath, S.: Heat-budget measurements on the Quelccaya ice cap, Peruvian Andes, J. Glaciol., 20, 85-97, 1978.

Huggel, C., Haeberli, W., Kääb, A., Hoelzle, M., Ayros, E., and Portocarrero, C.: Assessment of glacier hazards and glacier runoff for different climate scenarios based on remote sensing data: a case study for a hydropower plant in the Peruvian Andes, in: Proceedings of EARSeL-LISSIG-Workshop Observing our Cryosphere from Space, 2003.

IPCC: Climate Change 2007: The Physical Science Basis, Contribution of Working Group I to the Fourth Assessment Report of the Intergovernmental Panel on Climate Change, edited by: Solomon, S., Qin, D., Manning, M., Chen, Z., Marquis, M., Averyt, K. B., Tignor, M., and Miller, H. L., Cambridge University Press, Cambridge, United Kingdom and New York, NY, USA, 2007.

Kalnay, E., Kanamitsu; M., Kistler, R., Collins, W., Deaven, D., Gandin, L., Iredell, M., Saha, S., White, G., Woollen, J., Zhu, Y., Leetmaa, A., Reynolds, R., Chelliah, M., Ebisuzaki, W., Higgins, W., Janowiak, J., Mo, K. C., Ropelewski, J., Wang, J., Jenne, R., and Joseph, D.: The NCEP/NCAR 40-Year Reanalysis Project, Bull. Am. Meteorol. Soc., 77, 437-471., 1996.

Kaser, G.: Glacier-climate interaction at low latitudes, J. Glaciol., 47, 195-204, 2001.

Kaser, G. and Osmaston, H.: Tropical glaciers, Cambridge University Press, 2002.

Kaser, G., Juen, I., Georges, C., Gomez, J., and Tamayo, W.: The impact of glaciers on the runoff and the reconstruction of mass balance history from hydrological data in the tropical Cordillera Blanca, Peru, J. Hydrol., 282, 130-144, 2003.

Kitoh, A., Kusunoki, S., and Nakaegawa, T.: Climate change projections over South America in the late 21st century with the 20 and $60 \mathrm{~km}$ mesh Meteorological Research Institute atmospheric general circulation model (MRI-AGCM), J. Geophys. Res., 116, D06105, doi:10.1029/2010JD014920, 2011

Linsbauer, A., Paul, F., and Haeberli, W.: Modeling glacier thickness distribution and bed topography over entire mountain ranges with GlabTop: Application of a fast and robust approach, J. Geophys. Res., 117, F03007, doi:10.1029/2011JF002313, 2012

Lüthi, M. P., Bauder, A., and Funk, M.: Volume change reconstruction of Swiss glaciers from length change data, J. Geophys. Res. 115, F04022, doi:10.1029/2010JF001695, 2010.

Mark, B. G. and Seltzer, G.: Evaluation of recent glacier recession in the Cordillera Blanca, Peru (AD 1962-1999): spatial distribution of mass loss and climatic forcing, Quat. Sci. Rev., 24, 22652280, 2005.

Mark, B. G., Seltzer, G. O., Rodbell, D. T., and Goodman, A. Y.: Rates of deglaciation during the last glaciation and Holocene in the C. Vilcanota-Quelccaya Ice Cap region, southeastern Peru, Quat. Res., 57, 287-298, 2002. 
Meister, I.: Modelling and analysis of the subglacial topography of Jostedalsbreen, Norway, Master thesis, Department of Geogprahy, University of Zurich, 2010.

Minvielle, M. and Garreaud, R.: Projecting rainfall changes over the South American Altiplano, J. Climate, 24, 4577-4583, 2011.

Morales-Arnao, B. and Hastenrath, S.: Glaciers of Peru, in: Satellite Image Atlas of Glaciers of the World, edited by: Williams Jr., R. S. and Ferrigno, J. G., US Geological Survey Professional Paper 1386-I-4, 151-179, 1999.

Ohmura, A.: Physical basis for the temperature-based melt-index method, J. Appl. Meteorol., 40, 753-761., 2001.

Paltridge, G., Arking, A., and Pook, M.: Trends in middle- and upper-level tropospheric humidity from NCEP reanalysis data, Theor. Appl. Climatol., 98, 351-359, doi:10.1007/s00704-0090117-x, 2009.

Paterson, W. S. B.: The Physics of Glaciers, Pergamon, New York, 1994.

Paul, F. Kaab, A., Maisch, M., Kellenberger, T., and Haeberli, W.: The new remote-sensing-derived Swiss glacier inventory, I. Methods, Ann. Glaciol., 34, 355-361, 2002.

Paul, F., Barrand, N., Baumann, S., Berthier, E., Bolch, T., Casey, K., Frey, H., Joshi, S. P., Konovalov, V., Le Bris, R., Mölg, N., Nosenko, G., Nuth, C., Pope, A., Racoviteanu, A., Rastner, P., Raup, B., Scharrer, K., Steffen, S., and Winsvold, S.: On the accuracy of glacier outlines derived from remote sensing data, Ann. Glaciol., 54, 2013.

Peduzzi, P., Herold, C., and Silverio, W.: Assessing high altitude glacier thickness, volume and area changes using field, GIS and remote sensing techniques: the case of Nevado Coropuna (Peru), The Cryosphere, 4, 313-323, doi:10.5194/tc-4-313-2010, 2010.

Rabatel, A., Francou, B., Soruco, A., Gomez, J., Cáceres, B., Ceballos, J. L., Basantes, R., Vuille, M., Sicart, J.-E., Huggel, C., Scheel, M., Lejeune, Y., Arnaud, Y., Collet, M., Condom, T., Consoli, G., Favier, V., Jomelli, V., Galarraga, R., Ginot, P., Maisincho, L., Mendoza, J., Ménégoz, M., Ramirez, E., Ribstein, P., Suarez, W., Villacis, M., and Wagnon, P.: Review article of the current state of glaciers in the tropical Andes: a multicentury perspective on glacier evolution and climate change, The Cryosphere Discuss., 6, 2477-2536, doi:10.5194/tcd-6-24772012, 2012.

Rabus, B., Eineder, M., Roth, A., and Bamler, R.: The shuttle radar topography mission - a new class of digital elevation models acquired by spaceborne radar, ISPRS J. Photogramm., 57, 241262, 2003

Racoviteanu, A. E., Manley, W. F., Arnaud, Y., and Williams, M. W.: Evaluating digital elevation models for glaciologic applications: An example from Nevado Coropuna, Peruvian Andes, Global Planet. Change, 59, 110-125, 2007.

Racoviteanu, A. E., Arnaud, Y., Williams, M. W., and Ordonez, J.: Decadal changes in glacier parameters in the C. Blanca, Peru, derived from remote sensing, J. Glaciol., 54, 499-510, 2008.

Raup, B., Kääb, A., Kargel, J. S., Bishop, M. P., Hamilton, G., Lee, E., Paul, F., Rau, F., Soltesz, D., Khalsa, S. J., Beedle, M., and Helm, C.: Remote sensing and GIS technology in the Global Land Ice Measurements from Space (GLIMS) project, Comput. Geosci., 33, 104-125, 2007.

Reuter, H., Nelson, A., Strobl, P., Mehl, W., and Jarvis, A.: A first assessment of Aster GDEM tiles for absolute accuracy, relative accuracy and terrain parameters, in: Geoscience and Re- mote Sensing Symposium, IGARSS 2009, Geosci. Remote Sens. Sym., 5, 240-243, 2009.

Ruckstuhl, C., Philipona, R., Morland, J., and Ohmura, A.: Observed relationship between surface specific humidity, integrated water vapor, and longwave downward radiation at different altitudes, J. Geophys. Res., 112, D03302, doi:10.1029/2006JD007850, 2007.

Salzmann, N., Huggel, C., Calanca, P., Díaz, A., Jonas, T., Jurt, C., Konzelmann, T., Lagos, P., Rohrer, M., Silverio, W., and Zappa, M.: Integrated assessment and adaptation to climate change impacts in the Peruvian Andes, Adv. Geosci., 22, 41-49, 2009, http://www.adv-geosci.net/22/41/2009/.

Schwarb, M., Acuña, D., Konzelmann, Th., Rohrer, M., Salzmann, N., Serpa Lopez, B., and Silvestre, E.: A data portal for regional climatic trend analysis in a Peruvian High Andes region, Adv. Sci. Res., 6, 219-226, doi:10.5194/asr-6-219-2011, 2011.

Sicart, J. E., Wagnon, P., and Ribstein, P.: Atmospheric controls of heat balance of Zongo Glacier, $16^{\circ} \mathrm{S}$ Bolivia, J. Geophys. Res., 110, D12106, doi:10.1029/2004JD005732, 2005.

Sicart, J. E., Hock, R., and Six, D.: Glacier melt, air temperature, and energy balance in different climates: The Bolivian Tropics, the French Alps, and Northern Sweden, J. Geophys. Res., 113, D24113, doi:10.1029/2008JD010406, 2008.

Silverio, W. and Jaquet, J. M.: Glacial cover mapping (1987-1996) of the C. Blanca (Peru) using satellite imagery, Remote Sens. Environ., 95, 342-350, 2005.

Sobel, A. H, Nilsson J., and Polvani, L. M.: The weak temperature gradient approximation and balanced tropical moisture waves, J. Atmos. Sci., 58, 3650-3665, 2001.

Thompson, L. G., Hastenrath, S., and Arnao, B. M.: Climatic ice core records from the tropical Quelccaya Ice Cap, Science, 203, 1240-1243, 1979.

Thompson, L. G., Bolzan, J. F., Brecher, H. H., Kruss, P. D., Mosley-Thompson, E., and Jezek, K. C.: Geophysical investigations of the tropical Quelccaya ice cap, Peru, J. Glaciol., 28, 57-69, 1982.

Thompson, L. G., Mosley-Thompson, E., and Morales Arnao, B. M.: El Niño-Southern Oscillation events recorded in the stratigraphy of the tropical Quelccaya ice cap, Peru, Science, 226, 5053, 1984.

Thompson, L. G., Mosley-Thompson, E., Bolzan, J. F., and Koci, B. R.: A 1500-year record of tropical precipitation in ice cores from the Quelccaya ice cap, Peru, Science, 229, 971-974, 1985.

Thompson, L. G., Mosley-Thompson, E., Brecher, H., Davis, M., Leon, B. Les, D., Lin, P. N., Mashiotta, T., and Mountain, K. Abrupt tropical climate change: Past and present, P. Natl. Acad. Sci. USA, 103, 10536-10543. 2006.

Uppala, S.M., KÅllberg, P. W., Simmons, A. J., Andrae, U., Da Costa Bechtold, V., Fiorino, M., Gibson, J. K., Haseler, J., Hernandez, A., Kelly, G. A., Li, X., Onogi, K., Saarinen, S., Sokka, S., Allan, R. P., Andersson, E., Arpe, K., Balmaseda, M. A., Beljaars, A. C. M., Van de Berg, L., Bidlot, J., Bormann, N., Caires, S., Chevallier, F., Dethof, A., Dragosavac, M., Fisher, M., Fuentes, M., Hagemann, S., Hólm, E., Hoskins, B. J., Isaksen, L., Janssen, P. A. E. M., Jenne, R., Mcnally, A. P., Mahfouf, J.-F., Morcette, J.-J., Rayner, N. A., Saunders, R. W., Simon, P., Sterl, A., Trenberth, K. E., Untch, A., Vasiljevic, D., Viterbo, P., and Wollen, J.: The ERA-40 re-analysis, Quart. J. R. Meteorol. Soc., 131, 2961-3012, 2005. 
Urrutia, R. and Vuille, M.: Climate change projections for the tropical Andes using a regional climate model: Temperature and precipitation simulations for the end of the 21 st century, J. Geophys. Res., 114, D02108, doi:10.1029/2008JD011021, 2009.

Vergara, W., Deeb, A., Valencia, A., Bradley, R., Francou, B., Zarzar, A., Grünwaldt, A., and Haeussling, S.: Economic impacts of rapid glacier retreat in the Andes, Eos. Trans. AGU, 88, 261264, doi:10.1029/2007EO250001, 2007.

Vey, S., Dietrich, R., Rülke, A., and Fritsche, M.: Validation of Precipitable Water Vapor within the NCEP/DOE Reanalysis Using Global GPS Observations from One Decade, J. Climate, 23, ), 1675-1695, doi:10.1175/2009JCLI2787.1, 2009.

Vuille, M., Bradley, R. S., Werner, M., and Keimig, F.: 20th Century Climate Change in the Tropical Andes: Observations and Model Results, Clim. Change, 59, 75-99, 2003.

Vuille, M., Francou, B., Wagnon, P., Juen, I., Kaser, G., Mark, B.G., and Bradley, R. S.: Climate change and tropical Andean glaciers: Past, present and future, Earth Sci. Rev., 89, 79-96, 2008.
Willett, K. M., Jones, P. D., Thorne, P. W., and Gillett, N. P.: A comparison of large scale changes in surface humidity over land in observations and CMIP3 general circulation models, Environ. Res. Lett., 5, 025210, doi:10.1088/1748-9326/5/2/025210, 2010.

Wagnon, P., Ribstein, P., Kaser, G., and Berton, P.: Energy balance and runoff seasonality of a Bolivian glacier, Global Planet. Change, 22, 49-58, 1999.

WGMS: Glacier Mass Balance Bulletin No. 10 (20062007), edited by: Haeberli, W., Gärtner-Roer, I., Hoelzle, M., Paul, F., and Zemp, M., ICSU (WDS)/IUGG (IACS)/UNEP/UNESCO/WMO, World Glacier Monitoring Service, Zurich, Switzerland, pp. 96, 2009.

Zemp, M., Haeberli, W., Hoelzle, M., and Paul, F.: Alpine glaciers to disappear within decades?, Geophys. Res. Lett., 33, L13504, doi:10.1029/2006GL026319, 2006. 